\title{
Stanisław Michalczyk. 2010. Demokracja medialna. Teoretyczna analiza problemu. Toruń: Wydawnictwo Adam Marszałek, ss. 317
}

$\mathbf{N}$ ajnowsza książka Stanisława Michalczyka, medioznawcy, profesora Uniwersytetu Śląskiego, została zainspirowana wnikliwą obserwacją otaczającej rzeczywistości społeczno-politycznej i diagnozą stanu funkcjonowania w niej demokracji. A nie jest to ocena bynajmniej panegiryczna. Wolne media, które zapewniają m.in. komunikację między rządem i społeczeństwem, zostały zdominowane przez telewizję, która spłyca dyskurs, sprowadzając go do obrazu, a nie merytorycznej debaty, spycha na dalszy plan informację, dając pierwszeństwo sposobowi przekazu, wizerunkowi, wizualizacji treści. Demokracja jest osadzona w płaszczyźnie zakłamania i hipokryzji: z jednej strony nieustannie trwa proces emancypacji wyborców, z drugiej - cichego nimi sterowania. Umiejętność kierowania opinią publiczną urasta do rangi decydującej w toczącej się grze politycznej. Autor zwraca również uwagę na niejasność kryteriów w awansie politycznym - sukces częściej osiąga ten, kto jest wierny zwierzchnikowi, a nie ten, kto odważy się mu przeciwstawić, zdobywając się na zbytni indywidualizm. W konsekwencji obywatele w trakcie elekcji mają ograniczony wybór - rzadziej głosują na partię, z którą się utożsamiają, raczej przeciwko tej, którą chcą wyeliminować z aktywnego dyskursu politycznego. Demokracja coraz częściej opiera się na marketingu politycznym, ukierunkowanym na sprzedaż produktu politycznego. Efektem tego jest postępująca tabloidyzacja i entertainizacja polityki. Jak pisze Michalczyk: „Wyborcy-widzowie karmieni są spektaklami, a nie informacjami koniecznymi do podejmowania racjonalnych decyzji (kłótnie polityków, dziennikarzy, »ekspertów«). Medialna polityka powoli staje się niesterowna, a demokracja na niej oparta wykrzywiona, nieefektywna, nieracjonalna" (s. 8).

Autor pisze z dwóch punktów widzenia: jako obywatel-wyborca, odbiorca mediów, uczestnik procesów demokratycznych i jako naukowiec-medioznawca. Mogłoby się wydawać, że są to dwie nierozłączne płaszczyzny, jednak skrupulatne poruszanie się w każdej z nich pozwala swobodnie łączyć teorię z zakresu komunikowania z praktyką społeczną. Demokracja medialna bowiem to problem z jednej strony demokracji jako takiej, która jest środkiem do osiągnięcia celów społecznych. Z drugiej - nauki o komunikowaniu, która również służy optymalizacji procesów porozumiewania się w społeczeństwie. Stanisław Michalczyk, rozpo- 
czynając rozważania nad demokracją medialną, przywołuje starą zasadę sformułowaną przez Maxwella McCombsa i Donalda Shawa - Communication is central to democracy, która wyznacza ramy odniesień prezentowanych w książce.

Można odnieść wrażenie, że rozważania autora są próbą zareagowania na sposób funkcjonowania demokracji, na jej coraz większe wynaturzenia, które niejednokrotnie stają się udziałem mediów jako pośredników w przekazywaniu informacji między obywatelami-wyborcami a podmiotami politycznymi. Reakcja ta wynika z potrzeby systematyzacji i uporządkowania obserwowanych zjawisk, jak również próby ich wyjaśnienia. Książka w szczególności przybliża istotny aspekt tych zmian - powstanie i rozwój demokracji medialnej, która mieści w sobie wiele obszarów ważnych dla badaczy procesu komunikowania masowego, studentów dziennikarstwa, socjologii, politologii, komunikacji społecznej, ale również aktywnych kreatorów tej sfery - dziennikarzy czy pracowników PR. Wśród najistotniejszych Michalczyk omawia: teorię demokracji medialnej, jej uwarunkowania, konstruktywistyczne aspekty demokracji medialnej, zagadnienia entertainizacji polityki, politycznego managementu komunikacyjnego, opinii publicznej, która stanowi arenę demokracji medialnej. Całość wsparta jest szerokim kontekstem odniesień do światowej literatury przedmiotu, badań empirycznych oraz rekonstrukcji opinii analityków poszczególnych zagadnień.

Ujęcie tematu w książce jest szerokie i interdyscyplinarne. Autor wykorzystuje nie tylko zakres prezentowanej przez siebie specjalizacji - medioznawstwa, ale analizując zagadnienie, sięga również do dorobku innych nauk - psychologii (indywidualne motywy korzystania z mediów), socjologii (strukturalne uwarunkowania odbioru mediów), politologii (analiza funkcji wyborów), marketingu politycznego (kwestie kreowania wizerunku politycznego), filozofii (postmodernizm). Można zatem śmiało stwierdzić, że jest to prawdziwa praca z zakresu nauk społecznych, obejmująca szerokie spektrum pojęciowo-analityczne.

Jak wskazuje tytuł, książka stanowi rzeczywiście w dużej mierze teoretyczne studium problemu. Każde z przywoływanych w niej pojęć jest wnikliwie analizowane, rekonstruowane są stanowiska innych autorów w danej kwestii, przytaczane są klasyczne ujęcia oraz funkcjonujące w literaturze klasyfikacje i modele. Praca prezentuje szczegółową analizę publiczności medialnej - terminologiczną, etymologiczną, klasyfikacyjną, typologiczną, strukturalną. W podobnym zakresie kolejne rozdziały podejmują zagadnienia demokracji, komunikowania politycznego, medializacji, opinii publicznej, społeczeństwa medialnego, politycznego PR. I zapewne byłaby to kolejna, obok m.in. tych autorstwa Denisa McQuaila czy Macieja Mrozowskiego, pozycja, porządkująca zagadnienia medioznawcze, gdyby nie dwie kwestie.

Po pierwsze, liczne odniesienia do badań empirycznych, które ukazują możliwość zastosowania teorii w praktyce społecznej. Charakteryzując stanowiska teoretyczne postmodernistycznej logiki informacyjnej, autor wzmacnia je wynika- 
mi badań Günthera Lengauera, który prowadził eksploracje dotyczące treściowej struktury problematyki politycznej w mediach austriackich i niemieckich (s. 128-129). Wskaźniki medializacji partii są przedstawiane w odniesieniu do studium empirycznego o medializacji organizacji politycznych Patricka Dongesa (s. 160-162). Przy omawianiu komunikacji wyborczej przytacza szereg wyników badań zgromadzonych przez Mariusza Kolczyńskiego oraz Marka Mazura na podstawie przeprowadzonych przez nich analiz treści telewizyjnych w trakcie kampanii parlamentarnej i prezydenckiej 2005 roku (s. 270-272). Kwestie kształtowania wizerunku zostały wsparte wnioskami empirycznymi Doroty Dolińskiej, która rozpatrywała komunikację między elektoratem a partiami w latach 2000-2005 (s. 272). $Z$ kolei kampania wyborcza w mediach w okresie transformacji ustrojowej została zobrazowana eksploracjami Tomasza Mielczarka, na podstawie treści z Telewizji Polskiej SA (s. 273). Analizując poszczególne pojęcia, autor wizualizuje je licznymi przykładami - obok pojęć i terminów teoretycznych pojawiają się omówienia konkretnych blogów politycznych, przykłady Cyber-campaigning, studia przypadków skandali politycznych (m.in. Clinton-Lewinsky czy CDU-Spende-Afera).

Druga kwestia, która dodaje dynamiki teoretycznemu charakterowi książki, to osadzenie klasycznych treści we współczesnych realiach. W obliczu postępującego zacierania się różnic między państwami autor wskazuje na różnice w odbiorze mediów w różnych społecznościach międzynarodowych (s. 21-22). Przedstawia strategie największych koncernów medialnych w dobie kryzysu gospodarczego, aktualne wskaźniki użytkowania poszczególnych mediów w różnych krajach oraz ich uwarunkowania. Odrębnie Michalczyk omawia rozwój Internetu oraz społeczności sieciowej, w szczególności zwracając uwagę na takie państwa, jak: Rosja, USA, Niemcy, Japonia, Wielka Brytania oraz Polska (s. 57-71). W książce pojawiają się liczne analizy współczesnych przekazów reklamowych, kampanii wyborczych ostatnich lat, treści programów publicystycznych i informacyjnych, politycznych spektakli rozrywkowych z udziałem aktywnych polityków.

Demokrację medialną autor rozpatruje w kontekście zagrożeń i szans. Z jednej strony, media jako pośrednik demokracji, przekazują nam obraz polityki w dużej mierze nierzeczywisty, często trudny do zrozumienia, ale fascynujący - pełen dramaturgii, atmosfery grozy, pytań, na które wraz z dziennikarzami obywatele szukają odpowiedzi. „Ludzie zaczęli żyć w dwóch różnych historiach - w toczącej się realnie i w przekazywanej nam przez media. Historia medialna coraz bardziej staje się jedyną historią, jaką znamy. Wiemy tylko to, co wiemy z mediów" - w ten sposób Michalczyk sygnalizuje główny problem demokracji medialnej, odwołując się do refleksji Ryszarda Kapuścińskiego (s. 8). Z drugiej strony, biorąc pod uwagę fakt niemożności zahamowania analizowanych procesów, w zakończeniu książki autor stawia optymistyczne tezy. Wśród nich należy podkreślić postępujący proces edukacji medialnej, ukierunkowanej na naukę, szczególnie młodych ludzi, racjonalnego odbioru mediów, rozumienia ich działania, wyko- 
rzystywania środków masowego przekazu jako narzędzi rozwoju intelektualnego i pracy zawodowej.

Recenzowana praca jest bez wątpienia cenną i aktualną analizą problemu, która dzięki wielopłaszczyznowemu ujęciu tworzy spójną całość. Bez wątpienia może być wykorzystywana jako podręcznik (biorąc pod uwagę szczególnie jej wartość teoretyczną), ale również przewodnik dla praktyków instytucji demokratycznych i PR-owskich. Jasna formuła przekazu, porządkująca wiele myśli w formie wykresów i tabeli, zrozumiały język, przejrzysta struktura oraz walory merytoryczne predestynują ją do odegrania takiej właśnie roli. Osobiście proponuję ją każdemu, kto jako świadomy obywatel, odbiorca mediów masowych, uczestnik demokracji pragnie na chwilę zatrzymać się i podjąć refleksję nad procesami, w których bierzemy aktywny udział. Być może ich intensywność i dynamika, na co często zwraca uwagę Michalczyk w swej książce, utrudnia nam systematyczną ich analizę. Lektura ta stanowi wartościową przesłankę ku temu.

Agnieszka Turska-Kawa

(Uniwersytet Śląski w Katowicach) 